\title{
PROFITABILITY AND RESOURCE USE EFFICIENCY OF MAIZE SEED PRODUCTION IN PALPA DISTRICT OF NEPAL
}

\author{
M. Sapkota ${ }^{1^{*}}$, N.P. Joshi ${ }^{2}$, R.R. Kattel ${ }^{3}$ and M. Bajracharya ${ }^{4}$ \\ ${ }^{1}$ Nepal Agricultural Research Council, Khumaltar, Lalitpur, Nepal \\ ${ }^{2}$ Graduate School for International Development and Cooperation, Hiroshima University, Japan \\ ${ }^{3}$ Department of Agricultural Economics and Agribusiness Management, Agriculture and Forestry \\ University, Chitwan, Nepal \\ ${ }^{4}$ Ministry of Agricultural Development, District Agriculture Development Office, Baglung, Nepal
}

\begin{abstract}
The study aimed to analyze profitability and resource use efficiency of maize seed production in Palpa district of Nepal. Raosoft Inc. software was used to determine the sample size of 182 maize seed producers from the total 260 maize seed producers in the district. Data was collected using a pre-tested semi-structured questionnaire survey administered to the randomly selected samples. Results showed that the uses as well as cost of major inputs such as seed, labor, farmyard manure (FYM), and management/other cost including tillage were higher among small scale farmers compared to the large scale farmers. The average cost of production among small scale farmers was NRs. 94,195per hectare compared to NRs. 64,145among large scale farmers. A benefit cost ratio of maize seed production was higher for large scale farmers (1.12), which in case of small scale farmers was less than 1, i.e. 0.9 . Hence, maize seed production was found profitable only for large scale farmers. Resource use efficiency analysis showed FYM, tillage and labor were overused. This suggests that the use of FYM, tillage and labor should be decreased by 665,456 and 68 percent respectively. Similarly, cost on seed, chemical fertilizer and management/other were underused, hence, need to increase by 92,69 and 97 percent respectively for the optimum allocation of resources. Overall, maize seed production is profitable but resources should be optimally utilized and should be carried on larger scale.
\end{abstract}

Keywords: Maize seed, profitability, resources, resource use efficiency.

"Corresponding author email: sapkotamahes@gmail.com 


\section{INTRODUCTION}

Production and profitability of any crop depends upon the inputs used in the production process. Seed is very essential input in any agricultural production system. Seed is the most important, strategic and relatively inexpensive input that determines the crop yield (Langyintuo, 2005; Maredia \& Howard, 1998). It should be made easily available and should be efficiently used for an improvement of the livelihood and income of rural people. The yield of maize production in Nepal is 2.43 metric tons per hectare (AICC, 2016) which is less with compared to global yield records. The use of low quality/less potential seed and lack of proper crop management technologies along with low soil fertility are attributed to the low yield of maize in Nepal (Karki et al., 2015). Similarly, disease infestation at different stages of crop (Subedi, 2015) labor shortage (Joshi et al., 2012) and water stress condition due to drought (Khalili et al., 2013) are responsible for the lower yield. The haphazard and inefficient use of inputs or resources leads to wastage of time, money and effort which ultimately declines the yield and profitability of farm which leads to the weak agriculture economic growth.

There is a growing practice of using hybrid seed for maize production to meet the demand of poultry feed industry, which is annually increasing at 11 percent (IFPRI, 2010; KC et al., 2015). However, there is very limited amount of hybrid seed available in Nepal which is unable to meet the growing demand of maize seed. This provides an opportunity for Nepali farmer to produce hybrid maize seed, which usually has higher return than the non-seed production. For instance, the net return from hybrid maize seed production in Bangladesh was 50 percent higher compared to the non-seed producers (Haque et al., 2012). In response to this increasing demand of hybrid maize seed and the higher return from it, growing number of Nepali farmers are pursuing hybrid maize seed production in Nepal. However, there is a lack of study on its profitability and resource use efficiency. This type of study is crucial for promoting the hybrid maize seed production, by providing the relevant suggestions needed to improve the efficiency of inputs for better production. Hence, this study aimed to assess the profitability, level of resources usedand its efficiency in the maize seed production.

\section{MATERIALS AND METHODS}

The production of maize seed in Palpa district is practiced in consultation with District Agriculture Development Office (DADO) and Nepal Agricultural Research Council (NARC) which are responsible government entities working for the improvement of agriculture sector in Nepal. The production of maize seed was highest in Palpa district which was the main reason to select it for the study. Altogether there were 260 farmers involved in maize seed production through eight registered farmer groups and three cooperatives from nine Village Development Committees (VDCs) i.e. Pokharathok $(\mathrm{N}=91)$, Chirtungdhara $(\mathrm{N}=21)$, Bhairavsthan 
$(\mathrm{N}=32)$, Khasauli $(\mathrm{N}=38)$, Deurali $(\mathrm{N}=33)$, Rampur $(\mathrm{N}=9)$, Thimure $(\mathrm{N}=8)$, Kusumkhola $(\mathrm{N}=7)$ and Chidipani $(\mathrm{N}=6)$ and one municipality i.e. Tansen $(\mathrm{N}=15)$. So the total population size for this study was 260 . The required sample size was determined using Raosoft. Inc. which is considered as a scientific and standard technique for the determination of sample size (Raosoft, 2014). It recommended sample size to be 182 at 95 percent confidence level and four percent margin of error with about 50 percent response expected. The simple random sampling technique was used to select sample in order to avoid possible bias. The simple random sampling is considered as the best way as this provides an equal chance for a selection of the element from the sampling frame (Scheaffer, 1979). The sample mainly comprised the maize seed producers from Pokharathok $(n=75)$, Chirtungdhara $(n=15)$, Bhairavsthan $(n=28)$, Khasauli $(n=31)$, Deurali $(n=27)$ and Tansen $(n=6)$.

Pre-testing of questionnaire was done in Madanpokhara VDC with 10 respondents (5.5 percent of the sample size), which is common in pre-test of questionnaire (Perneger et al., 2015) and more relevant in our case constrained by the resources. The pre-tested questionnaire was administered to collect primary data in June, 2016. It is believed that the more and reliable information can be collected from the interactions between the participants. Focus group discussions (FGD) was done to gather collective information and also to verify the responses obtained in questionnaire survey. A total of four FGDs were conducted and a key informant interview (KII) was done with the crop development officer of DADO, Palpa; chairperson of cooperatives and farmer groups; lead and progressive farmers. Secondary data were collected from governmental and non-governmental organizations, cooperative and journals.

The average area under maize seed production was 0.32 hectare (i.e. 6.202 ropani). Those farmers who were involved in the production of maize seed above the average maize seed area ( $>0.32$ hectare) were categorized as large scale farmers and others $(<0.32$ hectare $)$ as small scale farmers.

\section{Benefit cost analysis}

Benefit cost ratio (BCR) is a widely used technique to evaluate the economic performance of any firm including agricultural farms. It is regarded as a quick and the easiest technique. BCR was calculated using the following formula:

$$
\mathrm{BCR}=\frac{\text { Total return (NRs.) }}{\text { Total cost of production (NRs.) }}
$$

Total return $=$ Price of maize seed $\times$ Total amount of maize seed produced

Total cost of production $=$ Summation of cost incurred for all inputs

Inputs considered seed, farmyard manure (FYM), chemical fertilizer, labor, tillage and management/other. Almost all sampled farmers are producing maize seed in their own farm without incurring any cost in land rent. Moreover, the value of land is more 
or less uniform across the study area. Hence, land cost is not included in this study.

\section{Estimation of efficiency ratios using Cobb-Douglas production function}

Cobb-Douglas production function was used to compute marginal value product (MVP) in order to determine the optimum, over and underuse of resources following Gujarati (2009).

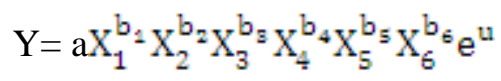

Transformed to linear form for ease in computation

$\ln Y=\ln a+b_{1} \ln X_{1}+b_{2} \ln X_{2}+b_{3} \ln X_{3}+b_{4} \ln X_{4}+b_{5} \ln X_{5}+b_{6} \ln X_{6}+u$

Where,

$\mathrm{Y}=$ Total income from maize seed production (NRs. per hectare)

$\mathrm{X}_{1}=$ Seed (NRs. per hectare)

$\mathrm{X}_{2}=\mathrm{FYM}$ (NRs. per hectare)

$\mathrm{X}_{3}=$ Chemical fertilizer (NRs. per hectare)

$\mathrm{X}_{4}=$ Labor (NRs. per hectare)

$\mathrm{X}_{5}=$ Tillage (NRs. per hectare)

$\mathrm{X}_{6}=$ Management/other (NRs. per hectare)

$\mathrm{u}=$ Error term

$\mathrm{a}=$ Intercept

$\ln =$ Natural logarithm

The efficiency ratio (r) was computed using the formula

$r=$ MVP/MFC

Where,

MFC $=$ Marginal factor cost

The MVP was estimated using the formula:

$\operatorname{MVP}_{\mathrm{i}}=\mathrm{b}_{\mathrm{i}} \times \frac{\mathrm{Y}}{z_{\mathrm{i}}}$

Where,

$b_{i}=$ Estimated regression coefficients

$\mathrm{Y}$ and $\mathrm{X}_{\mathrm{i}}$ are the values from geometric mean.

Decision criteria:

$r=1$ indicate the efficient use of resource

$r>1$ indicate underused of resource 
$r<1$ indicate overused of resource

The relative percentage change in MVP of each resource was estimated as:

$\mathrm{D}=(1-\mathrm{MFC} / \mathrm{MVP}) \times 100$

Or, $\mathrm{D}=(1-1 / \mathrm{r}) \times 100$

Where, $\mathrm{D}=$ Absolute value of percentage change in MVP of each resource

$\underline{\text { Return to scale analysis (RTS) }}$

The return to scale was calculated as follow:

$\mathrm{RTS}=\sum \mathrm{b}_{\mathrm{i}}$

Decision rule:

RTS $<1$ : Decreasing return to scale; percentage change in output is less than percentage change in input

$\mathrm{RTS}=1$ : Constant return to scale; percentage change in output is equal to percentage change in input

RTS> 1: Increasing return to scale; percentage change in output is more than percentage change in input

\section{RESULTS AND DISCUSSION}

\section{Inputs used in maize seed production}

The major inputs used in maize seed production were seed, labor, FYM, chemical fertilizer and tillage operation. The average amount of seed, labor, FYM, chemical fertilizer, tillage by tractor and tillage by bullock was found $23.08 \mathrm{~kg}, 184.47 \mathrm{man}$ days, $16145.13 \mathrm{~kg}, 56.94 \mathrm{~kg}, 2.33$ hours and 5.24 days per hectare, respectively. Small scale farmers used higher amount of seed $\left(24.97 \mathrm{~kg} \mathrm{ha}^{-1}\right)$ in comparison to large scale farmers $(20.11 \mathrm{~kg})$ and the difference was highly significant at one percent level. The reason of using higher amount of seed by small scale farmers was to replant the plant where there is no germination as they were found reluctant to take unnecessary burden of sowing seed again and also to minimize risk of germination. The labor used for maize seed production in large scale was almost half (133.58 man-days) to small scale (217.01 man-days). Farmers were found to care their farm more precisely in small area asit becomes easy to manage farm in a smaller area. The difference in the labor used was found statistically significant at one percent level.

Similarly, the FYM used by large scale farmers was significantly less $(13058.07 \mathrm{~kg}$ ) than small scale farmers $(18119.74 \mathrm{~kg})$. Whereas, higher use of chemical fertilizer $(60.38 \mathrm{~kg})$ by large scale farmers than that of small scale farmers $(54.74 \mathrm{~kg})$ was observed. However, the difference was statistically non-significant. Tractor usage (in hours) for tillage by large scale farmers was 2.17 hours which was less compared to small scale farmers (2.43 hours), the difference however, was statistically nonsignificant. The use of bullock for tillage in farm was found less among large scale 
farmers. The number of days required to till the farm of large scale farmers was 3.73 days and that of the small scale was 6.21 days and the difference was found statistically significant at onepercent level.

Table 1. Inputs used for maize seed production (per hectare)

\begin{tabular}{|c|c|c|c|c|c|c|}
\hline \multirow{2}{*}{$\begin{array}{l}\text { Variable cost } \\
\text { items }\end{array}$} & \multirow{2}{*}{ Overall } & \multicolumn{2}{|c|}{ Farm category } & \multirow{2}{*}{$\begin{array}{c}\text { Mean } \\
\text { difference }\end{array}$} & \multirow{2}{*}{ t-value } & \multirow[t]{2}{*}{$p$ - value } \\
\hline & & Large scale & Small scale & & & \\
\hline Seed (kg) & $23.08(8.57)$ & $20.11(4.05)$ & $24.97(10.06)$ & $-4.86 * * *$ & -3.873 & 0.000 \\
\hline Labor (man-days) & 184.47 (79.68) & $133.58(49.01)$ & $217.01(78.60)$ & $-83.43 * * *$ & -8.00 & 0.000 \\
\hline $\mathrm{FYM}^{1}(\mathrm{~kg})$ & $\begin{array}{c}16,145.13 \\
(14,732.44)\end{array}$ & $\begin{array}{l}13,058.07 \\
(8,023.92)\end{array}$ & $\begin{array}{c}18,119.74 \\
(17,495.15)\end{array}$ & $-5,061.66 * *$ & -2.287 & 0.023 \\
\hline $\begin{array}{l}\text { Chemical } \\
\text { fertilizer (kg) }\end{array}$ & $56.94(43.47)$ & $60.38(42.43)$ & $54.74(44.18)$ & 5.64 & 0.853 & 0.395 \\
\hline $\begin{array}{l}\text { Tillage tractor } \\
\text { (hour) }\end{array}$ & $2.33(2.89)$ & $2.17(2.17)$ & $2.43(3.27)$ & -0.26 & -0.595 & 0.552 \\
\hline $\begin{array}{l}\text { Tillage bullock } \\
\text { (days) }\end{array}$ & $5.24(5.68)$ & $3.73(3.79)$ & $6.21(6.44)$ & $-2.49 * * *$ & -2.944 & 0.004 \\
\hline
\end{tabular}

Notes: Figures in parentheses indicate percent. $* * *, * *$ indicate significant at $1 \%$ and $5 \%$ levels respectively.

${ }^{1} \mathrm{FYM}$ in kg was computed as: 1 doko cow/buffalo dung $=30 \mathrm{~kg}, 1$ doko goat manure $=20 \mathrm{~kg}$ and $1 \mathrm{bag}$ poultry manure $=30 \mathrm{~kg}$ (source: FGD and KII with DADO)

\section{Maize seed production cost}

Table 2, shows that the total cost of production for small scale farmers was more than that of large scale farmers. The average cost of seed, labor, FYM, chemical fertilizer, tillage and management/other was found to be NRs. 1,839.92, 45,048.04, 23,368.44, 1.657.70, 10,021.96 and 482.45 per hectare, respectively. The average seed cost under large scale farms was significantly less (NRs. 1,653.21) as compared to small scale farms (NRs. 2,047.89). The average seed cost for small scale was more because small scale farmers were found using more amount of seed per hectare to avoid the risk of no germination. The labor cost for maize seed production was found significantly higher in small scale farms NRs. 52,781.51 as compared to large scale farms NRs. 32,957.67 per hectare. Man-days required for carrying whole deposited FYM to field and manual shelling cost was found more for small scale farmers which had increased the labor cost. The majority of large scale farmers used shelling machine which decreased the labor cost highly as compared to small scale farmers. The average FYM cost of small scale farmers was found to be NRs. 25,799.67 per hectare and that of large scale farmers was NRs. 19,567.50 and the difference was significant at five percent level. All large and small scale farmers were found applying all the deposited FYM to the field which has increase the FYM cost for small scale farmers. 
Table 2. Comparative cost of maize seed production (NRs. per hectare)

\begin{tabular}{|c|c|c|c|c|c|c|}
\hline \multirow{2}{*}{ Variables } & \multirow{2}{*}{ Overall } & \multicolumn{2}{|c|}{ Farm category } & \multirow{2}{*}{$\begin{array}{c}\text { Mean } \\
\text { difference }\end{array}$} & \multirow{2}{*}{$\begin{array}{l}\mathrm{t}- \\
\text { value }\end{array}$} & \multirow{2}{*}{$\begin{array}{c}\mathrm{p}- \\
\text { value }\end{array}$} \\
\hline & & Large scale & Small scale & & & \\
\hline Seed & $\begin{array}{l}1,893.92 \\
(724.09)\end{array}$ & $\begin{array}{l}1,653.21 \\
(342.86)\end{array}$ & $\begin{array}{l}2,047.89 \\
(852.41)\end{array}$ & $-394.67 * * *$ & -3.711 & 0.000 \\
\hline Labor & $\begin{array}{c}45,048.04 \\
(20,092.25)\end{array}$ & $\begin{array}{c}32,957.67 \\
(12,852.65)\end{array}$ & $\begin{array}{c}5,2781.51 \\
(20,110.82)\end{array}$ & $-19,823.84 * * *$ & -7.392 & 0.000 \\
\hline FYM & $\begin{array}{c}23,368.44 \\
(19,869.21)\end{array}$ & $\begin{array}{c}19,567.50 \\
(13,370.68)\end{array}$ & $\begin{array}{c}25,799.67 \\
(22,815.47)\end{array}$ & $-6,232.17 * *$ & -2.083 & 0.039 \\
\hline Chemical fertilizer & $\begin{array}{c}1,657.70 \\
(1,430.81)\end{array}$ & $\begin{array}{c}1,717.39 \\
(1,332.40)\end{array}$ & $\begin{array}{c}1,619.53 \\
(1,495.03)\end{array}$ & 97.86 & 0.449 & 0.654 \\
\hline Tillage & $\begin{array}{l}10,021.96 \\
(6,189.28)\end{array}$ & $\begin{array}{c}7,883.94 \\
(3,215.43)\end{array}$ & $\begin{array}{l}11,389.53 \\
(7,184.40)\end{array}$ & $-3,505.59 * * *$ & -3.868 & 0.000 \\
\hline Management/other & $\begin{array}{c}482.45 \\
(700.98)\end{array}$ & $\begin{array}{c}365.42 \\
(404.99)\end{array}$ & $\begin{array}{c}557.30 \\
(830.46)\end{array}$ & $-191.88 *$ & -1.813 & 0.072 \\
\hline $\begin{array}{l}\text { Total cost of } \\
\text { production }\end{array}$ & $\begin{array}{c}82,472.51 \\
(38,808.03)\end{array}$ & $\begin{array}{c}64,145.13 \\
(24,230.93)\end{array}$ & $\begin{array}{c}94,195.42 \\
(41,821.59)\end{array}$ & $-30,050.29 * * *$ & -5.490 & 0.000 \\
\hline
\end{tabular}

Notes: Figures in parentheses indicate standard deviation. $* * *, * *$ and $*$ indicate significance at $1 \%, 5 \%$ and $10 \%$ levels respectively.

The average cost of chemical fertilizer for large scale and small scale farmers was NRs. 1,717.39 and 1,619.53 per hectare, respectively, however, the difference was statistically non-significant. The cost on tillage for large scale and small scale farmers was NRs. 7,883.94 and 11,389.53 per hectare respectively. The difference on tillage cost was found statistically significant at one percent level. The large scale farmers generally use tractor for land preparation which lowered the cost. The management/other cost of large scale and small scale farmers was NRs. 365.42 and 557.30 per hectare and the difference was statistically significant at 10 percent level. The total cost of maize seed production was found NRs. 82,472.51. The total cost of production for small scale farmer was NRs. 30,050.3 more than that of the large scale farmers. The difference in cost of production was statistically significant at one percent level. The share of labor cost (55\%) was high followed by FYM (28\%), tillage $(12 \%)$, seed $(2 \%)$, chemical fertilizer $(2 \%)$ and management/other $(1 \%)$ (Figure 1). This revealed that the huge amount of money (83\%) was spent on labor and FYM. Both these inputs are usually supplied from the household itself. Hence, it can be implied that maize seed production remains an important enterprise for the use of FYM produced by their own livestock as well as household labor. 


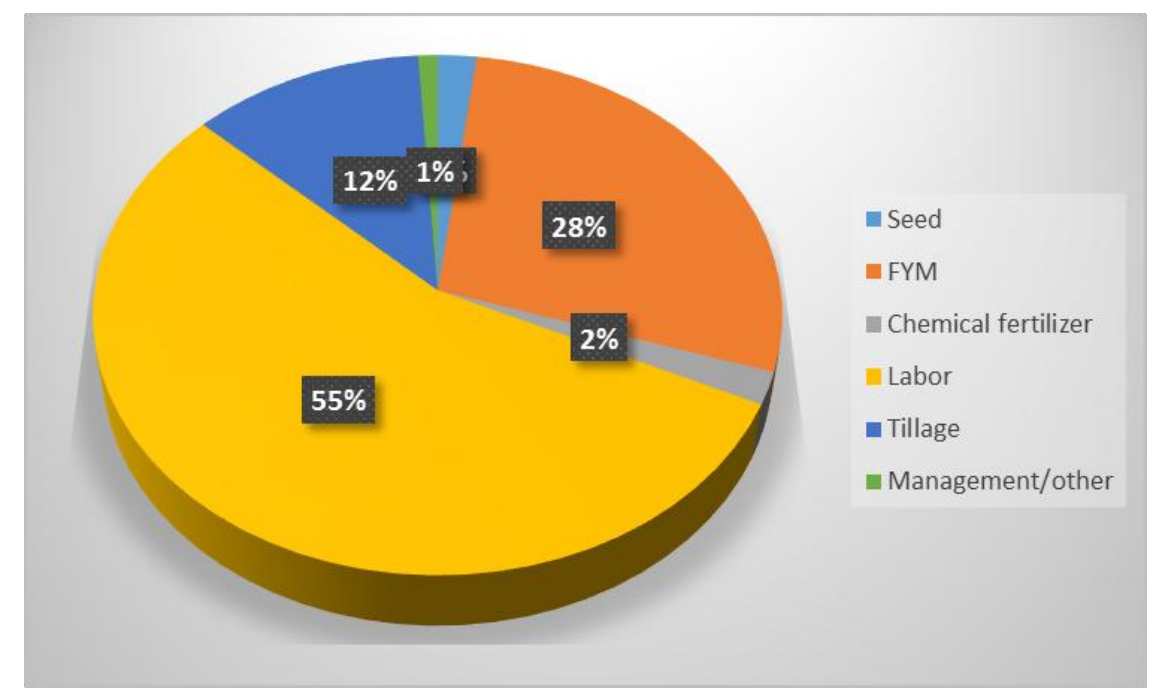

Figure 1. Share of different cost components to total cost of maize seed production

Bhandari et al. (2015) stated the total cost of maize production per hectare was NRs. $65,112.80$ in the nine hilly district of Nepal. A study by Bhandari et al. (2014) found the average cost of cultivation of maize production was NRs. 59,763.20 in the Palpa district. The total cost of production calculated in this study was higher because maize seed production requires intensive care and management than maize for grain cultivation. Moreover, it involves the cost of inspection, rouging, certification, sorting, grading and packaging.

\section{Yield and profitability of maize seed}

The average maize production per household (both as a seed and grain) for large scale and small scale farmers was $755.28 \mathrm{~kg}$ and $342.90 \mathrm{~kg}$ respectively. The difference in production per household was found statistically significant at one percent level. The average yield of maize seed production was $1,636.11 \mathrm{~kg}$ in the study area. The yield of maize seed production was $1,503.18 \mathrm{~kg}$ and $1,721.14 \mathrm{~kg}$ for large scale and small scale farmers respectively and the difference was statistically significant at 10 percent level. More FYM application and the better management practice (weeding, thinning and rouging) has increased the yield of small scale farmers.

The returns from maize seed was the summation of the returns from quality seed, grain used in feed and consumption, stovers and cone of maize. The returns and profitability from maize seed production was NRs. 75,733.07 and -6,739.44 (loss) in the study area. The returns from the maize seed production was found higher in small scale i.e. NRs. 79,384.44 than that of large scale i.e. NRs. 70,024.60. It might be due to significantly higher yield achieved by the small scale farmers. There was loss of 
NRs. $14,810.99$ in small scale farming and profit of NRs. 5,879.47 in large scale farming. This loss in small scale was due to the high cost involved in production, specifically labor and FYM. Thus, despite the loss they perceive maize seed production to have a lower opportunity cost compared to the maize production for grain. The benefit cost ratio of large scale farmers was found higher (1.12) than that of small scale farmers (0.90). This indicated that, in large scale farmers, one rupee spent on production yields benefit of NRs. 0.12 but there was a loss of NRs. 0.1 in the case of small scale farmers. The difference was found statistically significant at one percent level. The low BCR was due to high cost of FYM and labor (mainly the family labor). The FYM was applied at the time of land preparation of maize seed which is also utilized by other crops in a year. Family members were more engaged in agricultural operations which had increased the share of labor cost.

\section{Estimation of efficiency ratios using Cobb-Douglas production function}

The overall $\mathrm{F}$ value was 18.13 and it was statistically significant at one percent level which implies that the explanatory variables included in the model are important for the explanation of variation in dependent variable. The $\mathrm{R}^{2}$ value was 0.383 which indicates that about 38 percent of variation in the maize income was explained by the explanatory variables. The multicollinearityfwas checked using Variance inflation factor (VIF) and there was no problem of multicollinearity. The efficiency ratio less than one indicated that the FYM, tillage and labor were overused in the study area whereas seed, chemical fertilizer and management/other were underused resources. The value of efficiency ratios indicated that the inputs were not allocatively efficient. For optimum allocation of resources, cost on FYM, tillage and labor is to be decreased by 665,456 and 68 percent respectively and cost on seed, chemical fertilizer and management/other cost should be increased by 92, 69 and 97 percent respectively (Table 4).

Table 3. Yield and profitability of maize seed production

\begin{tabular}{|c|c|c|c|c|c|c|}
\hline \multirow{2}{*}{ Particulars } & \multirow{2}{*}{ Overall } & \multicolumn{2}{|c|}{ Farm category } & \multirow{2}{*}{$\begin{array}{c}\text { Mean } \\
\text { difference }\end{array}$} & \multirow{2}{*}{$\begin{array}{c}\mathrm{t}- \\
\text { value }\end{array}$} & \multirow{2}{*}{$\begin{array}{c}\mathrm{p}- \\
\text { value }\end{array}$} \\
\hline & & Large scale & Small scale & & & \\
\hline $\begin{array}{l}\text { Production in } \\
\text { household }(\mathrm{kg})\end{array}$ & $\begin{array}{c}503.77 \\
(398.89)\end{array}$ & $\begin{array}{c}755.28 \\
(516.25)\end{array}$ & $\begin{array}{c}342.90 \\
(158.97)\end{array}$ & $412.39 * * *$ & 7.864 & 0.000 \\
\hline Yield $\left(\mathrm{kg} / \mathrm{h}^{-1}\right)$ & $\begin{array}{l}1,636.11 \\
(749.97)\end{array}$ & $\begin{array}{l}1,503.18 \\
(702.47)\end{array}$ & $\begin{array}{l}1,721.14 \\
(769.91)\end{array}$ & $-217.96 *$ & -1.927 & 0.056 \\
\hline $\begin{array}{l}\text { Returns } \\
\text { (NRs./ha) }\end{array}$ & $\begin{array}{c}75,733.07 \\
(38,151.58)\end{array}$ & $\begin{array}{c}70,024.60 \\
(36,125.38)\end{array}$ & $\begin{array}{c}79,384.44 \\
(39,115.99)\end{array}$ & $-9,359.84$ & -1.622 & 0.107 \\
\hline Profit (NRs/ha) & $\begin{array}{c}-6,739.44 \\
(38,505.01)\end{array}$ & $\begin{array}{c}5,879.47 \\
(29,178.83)\end{array}$ & $\begin{array}{l}-14,810.99 \\
(41,584.67)\end{array}$ & $20,690.45 * * *$ & 3.655 & 0.000 \\
\hline BCR & $0.98(0.43)$ & $1.12(0.48)$ & $0.90(0.38)$ & $0.22 * * *$ & 3.464 & 0.001 \\
\hline
\end{tabular}

Notes: Figures in parentheses indicate standard deviation. $* * *$ and $*$ indicate significant at $1 \%$ and $10 \%$ levels, respectively. p-values are result of t-test. 
Table 4. Estimation of elasticity, MVP and efficiency ratios

\begin{tabular}{|c|c|c|c|c|c|c|c|}
\hline Variables & Coefficient & $\begin{array}{l}\text { Standard } \\
\text { error }\end{array}$ & $\begin{array}{c}\mathrm{t} \\
\text { value }\end{array}$ & MVP & MFC & $\mathrm{r}$ & D \\
\hline Seed cost & $0.338 * * *$ & 0.109 & 3.112 & 12.650 & 1 & 12.650 & 92.095 \\
\hline FYM Cost & 0.032 & 0.022 & 1.453 & 0.131 & 1 & 0.131 & 664.698 \\
\hline $\begin{array}{l}\text { Chemical Fertilizer } \\
\text { cost }\end{array}$ & $0.012 *$ & 0.006 & 1.838 & 3.245 & 1 & 3.245 & 69.179 \\
\hline Labor cost & $0.364 * * *$ & 0.091 & 4.016 & 0.595 & 1 & 0.595 & 68.083 \\
\hline Tillage Cost & -0.036 & 0.064 & -0.561 & -0.281 & 1 & -0.281 & 456.250 \\
\hline $\begin{array}{l}\text { Management/other } \\
\text { cost }\end{array}$ & $0.151 * * *$ & 0.033 & 4.619 & 33.195 & 1 & 33.195 & 96.987 \\
\hline Constant & $3.805 * * *$ & 0.862 & 4.416 & & & & \\
\hline Observations & 182 & & & & & & \\
\hline$F$ value $(6,175)$ & 18.13 & & & & & & \\
\hline Prob $>F$ & 0.000 & & & & & & \\
\hline R-Squared & 0.383 & & & & & & \\
\hline Adj. R-Squared & 0.362 & & & & & & \\
\hline Return to scale & 0.861 & & & & & & \\
\hline
\end{tabular}

Note: $* * *, *$ indicate significant at $1 \%$ and $10 \%$ level respectively.

Increase in cost of seed and chemical fertilizer was in accordance with the findings of Dhakal et al. (2015); Ghimire and Dhakal (2014); Sharma (2009); Gani and Omomona (2009); Ojo, Salami and Mohammed (2008) and in contrary with Chapke, Mondal and Mishra, (2011). Similarly, decreasing cost of FYM is supported by results of Ojo et al. (2008). Danso-Abbeam, Dahamani and Bawa (2015) and Ghimire and Dhakal (2014) has figured similar results of reducing labor cost for optimum allocation. Return to scale analysis showed value of 0.861 which indicates decreasing return to scale in the study area and this finding was in line with the findings of Gani and Omomona (2009) who found decreasing return to scale (0.961) on small scale irrigated maize producers in Nigeria and it was contrary to the findings of Olarinde (2011) who found increasing return to scale among the maize farmers in Nigeria.

\section{CONCLUSION}

From this study, we conclude that maize seed production is profitable in case of large scale farms whereas small scale farms have to bear loss. Therefore, maize seed production is recommended in larger land area so that there is minimization in costs of inputs and thus higher profitability can be obtained. Yield was observed higher in small scale farms due to better managerial activities. Hence, despite suffering a loss, the small scale farmers still find it as a better choice considering the lower opportunity cost of maize seed production. This shows that the district is potential for 
maize seed production. Application of better cultivation practices (manures and fertilizers, rouging, weeding) and using quality seed for seed production can increase yield of maize seed production in the study area. This study also identified that inputs used in maize seed production were inefficiently utilized. Cost on seed, chemical fertilizer and management activities need to be increased whereas cost on FYM, labor and tillage should be decreased in the study area. This will lead to optimal allocation of the resources resulting in the increased profitability.

\section{ACKNOWLEDGEMENTS}

The authors would like to acknowledge Directorate of Research and Extension, Agriculture and Forestry University, Chitwan for partial funding to accomplish this study.

\section{REFERENCES}

AICC. (2016). Krishi Diary. Agriculture Information and Communication Centre. Ministry of Agricultural Development, Department of Agriculture, Hariharbhawan, Lalitpur.

Bhandari, N.B., Bhattarai, D., and Aryal, M. (2014). Cost, production and price spread of cereals crops in Nepal: A time series analysis. Agribusiness Promotion and Marketing Development Directorate, Market Research \& statistics Management Program, Department of Agriculture, Ministry of Agriculture Development, Government of Nepal, Hariharbhawan, Lalitpur.

Bhandari, N.B., Bhattarai, D., and Aryal, M. (2015). Cost, production and price spread of cereals crops in Nepal: A time series analysis. Agribusiness Promotion and Marketing Development Directorate, Market Research \& statistics Management Program, Department of Agriculture, Ministry of Agriculture Development, Government of Nepal, Hariharbhawan, Lalitpur.

Chapke, R.R., Mondal, B., and Mishra, J.S. (2011). Resource-use efficiency of sorghum (Sorghum bicolor) production in rice (Oryza sativa)-fallows in Andhra Pradesh, India. Journal of Human Ecology, 34(2), 87-90.

Danso-Abbeam, G., Dahamani, A.M., and Bawa, G.A.(2015). Resource-use-efficiency among smallholder groundnut farmers in Northern Region, Ghana. American Journal of Experimental Agriculture, 6(5), 290.

Dhakal, S.C., Regmi, P.P., Thapa, R.B., Sah, S.K., and Khatri-Chhetri, D.B.(2015). Productivity and profitability of maize-pumpkin mix cropping in Chitwan, Nepal. Journal of Maize Research and Development, 1(1), 112-122.

Gani, B.S., and Omonona, B.T. (2009). Resource use efficiency among small-scale irrigated maize producers in Northern Taraba State of Nigeria. Journal of Human Ecology, 28(2),113-119.

Ghimire, B., and Dhakal, S.C.(2014). Production Economics of Sustainable Soil Management Based Cauliflower (Brassica oleracea L. Var. Botrytis) in Dhading District of Nepal. American Journal of Agriculture and Forestry, 2(4), 199-205. doi:10.11648/j.ajaf.20140204.23 
Gujarati, D.N. (2009). Basic econometrics. Tata McGraw-Hill Education.

Haque, M.A., Rahman, M.S., and Alam, Q.M. (2012).Profitability of Hybrid Maize (Zea mays L.) Seed Production under Contract Farming in Bangladesh: A Farm Level Study. Bangladesh Journal of Agricultural Research, 37(2), 327-334.

IFPRI. (2010).Ensuring Food and Nutritional Security in Nepal: A Stocktaking Exercise. International Food Policy Research Institute, Kathmandu, Nepal: USAID

Joshi, K.D., Conry, C., and Witcombe, J.R. (2012).Agriculture, seed, and innovation in Nepal: Industry and policy issues for the future. Project Paper. International Food Policy Research Institute. www.ifpri.org.

Karki, T.B., K.C.G., Shrestha, J., and Yadav, J.P. (2015). Tillage and planting density affect the performance of maize hybrids in Chitwan, Nepal. Journal of Maize Research and Development, 1(1), 10-20, doi: 10.5281/zenodo.34285.

KC, G., Karki, T.B., Shrestha, J., and Achhami, B.B. (2015).Status and prospects of maize research in Nepal. Journal of Maize Research and Development, 1(1), 1-9, doi: 10.5281/zenodo.34284.

Khalili, M., Naghavi, M.R., Aboughadareh, A.P., and Rad, H.N. (2013).Effects of drought stress on yield and yield components in maize cultivars (Zea mays L.). International Journal of Agronomyand Plant Production. 4, 809 -812.

Langyintuo, A.S. (2005).Maize production systems for Zimbabwe: Setting indicators for impact assessment and targeting. Research Project on strengthening seed marketing incentives in southern Africa to increase impact of maize breeding. International Maize and wheat improvement centre (CIMMYT), Harare, Zimbabwe.

Maredia, M.K., and Howard, J.A. (1998).Facilitating seed sector transformation in Africa: Key findings from the literature (No. 11366). Michigan State University, Department of Agricultural, Food, and Resource Economics.

Ojo, M.A., Salami, A.E., and Mohammed, U.S. (2008).Profitability, inputs elasticities and resource-use efficiency in small scale cowpea production in Niger state, Nigeria. Journal of Agriculture and Social Research, 8(2).

Olarinde, L.O. (2011).Analysis of technical efficiency differentials among maize farmers in Nigeria. The African Economic Research Consortium. Ladoke Akintola University of Technology, Nigeria. ISBN: 978-9966-023-04-9.

Perneger, T.V., Courvoisier, D.S., Hudelson, P.M., and Gayet-Ageron, A. (2015).Sample size for pre-tests of questionnaires. Quality Life of Research, 24(1), 147-151.

Raosoft.(2014).Sample size calculator. Retrieved September 9, 2017 from http://www.raosoft.com/samplesize.html.

Scheaffer, R. (1979). Elementary Survey Sampling. Massachusetts, USA, Duxbury Press.

Sharma, I.(2009). Economics of true potato seed and conventional potato cultivation practices in Rupandehi district, Nepal. M.Sc. Thesis, IAAS, Rampur, Chitwan, Nepal. pp. 40-44.

Subedi, S.(2015).A review on important maize diseases and their management in Nepal. Journal of Maize Research and Development, 1(1), 28-52, doi: 10.5281/zenodo.34260 